\title{
Further Evidence of Contrasting Phenotypes Caused by Reciprocal Deletions and Duplications: Duplication of NSD1 Causes Growth Retardation and Microcephaly
}

\author{
J.A. Rosenfeld ${ }^{a} \quad$ K.H. Kim ${ }^{b} \quad$ B. Angle ${ }^{b} \quad$ R. Troxell ${ }^{c} \quad$ J.L. Gorskic $\quad$ M. Westemeyer ${ }^{d}$

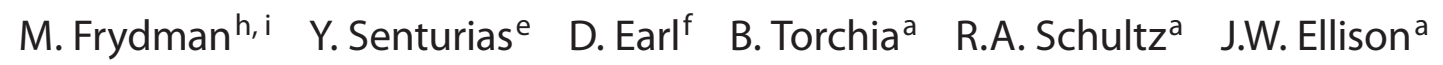 \\ K. Tsuchiya ${ }^{f} \quad$ S. Zimmerman ${ }^{g} \quad$ T.A. Smolarek ${ }^{g} \quad$ B.C. Ballifa $\quad$ L.G. Shaffer ${ }^{a}$ \\ a Signature Genomic Laboratories, PerkinElmer, Inc., Spokane, Wash., b Ann and Robert Lurie Children's Hospital of \\ Chicago, Chicago, Ill., ' University of Missouri School of Medicine, Columbia, Mo., dUniversity of Illinois College of \\ Medicine, Peoria, III., 'Weisskopf Child Evaluation Center, University of Louisville, Louisville, Ky., fSeattle Children's \\ Hospital, Seattle, Wash., and ${ }^{9}$ Cincinnati Children's Hospital Medical Center, Cincinnati, Ohio, USA; hanek Gertner \\ Genetics Institute, Chaim Sheba Medical Center, Tel Hashomer, and 'Sackler School of Medicine, Tel Aviv University, \\ Tel Aviv, Israel
}

\section{Key Words}

aCGH - Duplication - Growth retardation - Microcephaly •

NSD1 $\cdot$ Sotos syndrome $\cdot 5 q 35$

\begin{abstract}
Microduplications of the Sotos syndrome region containing NSD1 on $5 \mathrm{q} 35$ have recently been proposed to cause a syndrome of microcephaly, short stature and developmental delay. To further characterize this emerging syndrome, we report the clinical details of 12 individuals from 8 families found to have interstitial duplications involving NSD1, ranging in size from $370 \mathrm{~kb}$ to $3.7 \mathrm{Mb}$. All individuals are microcephalic, and height and childhood weight range from below average to severely restricted. Mild-to-moderate learning disabilities and/or developmental delay are present in all individuals, including carrier family members of probands; dysmorphic features and digital anomalies are present in a majority. Craniosynostosis is present in the individual with the largest duplication, though the duplication does not include MSX2, mutations of which can cause craniosynostosis,
\end{abstract}

on 5q35.2. A comparison of the smallest duplication in our cohort that includes the entire NSD1 gene to the individual with the largest duplication that only partially overlaps NSD1 suggests that whole-gene duplication of NSD1 in and of itself may be sufficient to cause the abnormal growth parameters seen in these patients. NSD1 duplications may therefore be added to a growing list of copy number variations for which deletion and duplication of specific genes have contrasting effects on body development.

Copyright $\odot 2013$ S. Karger AG, Basel

As our understanding of the phenotypic consequences of genomic copy number variations (CNVs) increases, several examples of opposite phenotypes for deletions and duplications have emerged. Many of these phenotypes involve growth, with deletions and duplications

J.A.R., B.T., R.A.S., and J.W.E. are all employees of Signature Genomic Laboratories, a subsidiary of PerkinElmer, Inc.

\section{KARGER}

Fax +4161306 1234

E-Mail karger@karger.ch

www.karger.com
(C) 2013 S. Karger AG, Basel

1661-8769/12/0036-0247\$38.00/0

Accessible online at:

www.karger.com/msy
Lisa G. Shaffer, PhD

Genetic Veterinary Sciences, Inc.

850 E Spokane Falls Boulevard

Spokane, WA 99202 (USA)

E-Maillshaffer@pawprintgenetics.com 
having opposite effects on weight (e.g. proximal 16p11.2 microdeletion and microduplication or 17p11.2 in SmithMagenis and Potocki-Lupski syndromes) [Jacquemont et al., 2011; Lacaria et al., 2012] or head size (e.g. proximal 16p11.2 or distal 1q21.1) [Brunetti-Pierri et al., 2008; Shinawi et al., 2010]. Similar opposite phenotypic effects have been proposed for behavioral phenotypes, such as those seen in Smith-Magenis and Potocki-Lupski syndromes or Williams-Beuren syndrome and its reciprocal duplication [Crespi et al., 2009]. Head growth and behavioral phenotypes have been proposed to be functionally related, with a correlation between the tendencies toward larger head sizes and autism spectrum disorders with some CNVs versus smaller head sizes and schizophrenia with their reciprocal copy state [Crespi et al., 2010]. Further functional support for this model of opposite phenotypes is provided by single-gene disorders in which activating mutations have opposite phenotypic effects from haploinsufficiency or dominant negative mutations. Many of these examples are also related to growth, such as mutations in the $A K T$ genes with activating mutations in $A K T 1$ causing Proteus syndrome [Lindhurst et al., 2011], in AKT2 causing hypoglycemia and overgrowth [Hussain et al., 2011] and in AKT3 causing megalencephaly [Poduri et al., 2012; Riviere et al., 2012], whereas loss of gene function causes growth restriction ( $A k t 1$ mouse model) [Chen et al., 2001], hyperglycemia and lipodystrophy (AKT2) [George et al., 2004], and microcephaly (AKT3) [Ballif et al., 2012]. Similarly, gain of function of FGFR 3 causes achondroplasia and other skeletal dysplasias, whereas loss of function causes tall stature in CATSHL (camptodactyly, tall stature and hearing loss) syndrome [Foldynova-Trantirkova et al., 2012]. In skull development, gain of function of MSX2 or duplication of $M M P 23 A / B$ causes craniosynostosis, whereas loss of function or deletion causes parietal foramina or late-closing fontanelles, respectively [Jabs et al., 1993; Wilkie et al., 2000; Gajecka et al., 2005].

Sotos syndrome is an autosomal dominant childhood overgrowth syndrome with additional features of characteristic dysmorphisms, mild-to-severe learning disabilities (LD) and advanced bone age. Some individuals may have cardiac or renal defects, seizures and/or scoliosis. The majority of affected individuals have heterozygous loss-of-function mutations within NSD1 [Tatton-Brown et al., 2005a]. The syndrome can also be caused by heterozygous deletion of NSD1, and some of these deletions are caused by recombination between homologous lowcopy repeats on $5 \mathrm{q} 35$ that mediate recurrent $\sim 2.0-\mathrm{Mb}$ deletions [Mochizuki et al., 2008]. Approximately 15\% of
Sotos syndrome in individuals of European ancestry are due to these recurrent or other atypical deletions [Douglas et al., 2005]; among individuals of Japanese ancestry, a common polymorphic inversion of the chromosomal region has led to $\sim 50 \%$ of Sotos syndrome being caused by NSD1 deletions [Kurotaki et al., 2003; Visser et al., 2005]. Reciprocal duplications of 5q35 encompassing NSD1 have been proposed to cause a syndrome opposite to Sotos, characterized by growth retardation, microcephaly, developmental delay, and delayed bone age [Chen et al., 2006; Kirchhoff et al., 2007; Franco et al., 2010; Busse et al., 2011; Zhang et al., 2011]. To better understand and characterize the contribution of NSD1 duplication to growth retardation and any other developmental phenotypes, we report clinical details of 12 affected individuals from 8 families known to have interstitial duplications involving NSD1.

\section{Methods}

From May 2004 to February 2012, samples from 53,059 probands were sent to Signature Genomic Laboratories for microarray-based comparative genomic hybridization (aCGH). Samples from 24,736 probands were analyzed on bacterial artificial chromosome (BAC)-based arrays (SignatureChip versions 1-4 and WG, Signature Genomic Laboratories, Spokane, Wash., USA), and 28,323 probands' samples were analyzed using whole-genome oligonucleotide-based arrays (SignatureChipOS version 1, 105K manufactured by Agilent Technologies, Santa Clara, Calif., USA, or versions 2 or $3,135 \mathrm{~K}$ manufactured by Roche NimbleGen, Madison, Wisc., USA; all custom designed by Signature Genomics) according to previously described methods [Bejjani et al., 2005; Ballif et al., 2008a, b; Duker et al., 2010]. All versions of the arrays have probe coverage of NSD1. Samples that had interstitial duplications involving NSD1 identified by BAC arrays were rerun on an oligonucleotide-based array to refine the breakpoint locations. Additional individuals were identified following clinical aCGH testing at Seattle Children's Hospital, using a whole-genome, 105K-feature, oligonucleotide-based array (SignatureSelect 1.1, custom-designed by Signature Genomics, manufactured by Agilent Technologies) or a whole-genome, 135K-feature, oligonucleotide-based array (NimbleGen CGX, custom designed by Signature Genomics, manufactured by Roche NimbleGen) or at Cincinnati Children's Hospital, using a whole-genome, single nucleotide polymorphism-based array (610Quad SNP, Illumina, San Diego, Calif., USA), all according to manufacturers' instructions. Subjects identified at Signature Genomics had their duplications visualized through metaphase and interphase fluorescence in situ hybridization (FISH) with BAC clone RP11-99N22 or RP11-15L12, according to previously described methods [Traylor et al., 2009]. When available, parental samples were also analyzed using interphase FISH. Either de-identified clinical information was supplied, or informed consent for publication of clinical information and photographs was obtained according to a protocol approved by the Institutional Review Board-Spokane. 
Table 1. Clinical features of individuals with NSD1 duplications

\begin{tabular}{|c|c|c|c|c|c|c|c|c|c|}
\hline Subject & 1 & 2 & 3 & 4 & $5 a$ & $5 b$ & 6 & 7 & 8 \\
\hline Age & $13 y$ & 2 y $9 \mathrm{~m}$ & $21 \mathrm{~m}$ & 2 y $5 \mathrm{~m}$ & $4 y$ & $2 y$ & $16 \mathrm{~m}$ & $8 y$ & $3 y$ \\
\hline $\begin{array}{l}\text { Duplication } \\
\text { coordinates } \\
\text { (hg18) }\end{array}$ & $\begin{array}{l}\text { chr5: } \\
175417567- \\
177076245\end{array}$ & $\begin{array}{l}\text { chr5: } \\
175512657- \\
177360321\end{array}$ & $\begin{array}{l}\text { chr5: } \\
175512657- \\
177360321\end{array}$ & $\begin{array}{l}\text { chr5: } \\
175512657- \\
177360321\end{array}$ & $\begin{array}{l}\text { chr5: } \\
175648881- \\
177316439\end{array}$ & $\begin{array}{l}\text { chr5: } \\
175512657- \\
177360321\end{array}$ & $\begin{array}{l}\text { chr5: } \\
175747659- \\
177319010\end{array}$ & $\begin{array}{l}\text { chr5: } \\
176395876- \\
176761282\end{array}$ & $\begin{array}{l}\text { chr5: } \\
176534825- \\
180189576\end{array}$ \\
\hline Inheritance & unknown & de novo & unknown & maternal & $\begin{array}{l}\text { likely maternal } \\
\text { (5a and } 5 b \text { mate }\end{array}$ & ernal half-sibs) & de novo & maternal & not maternal \\
\hline $\begin{array}{l}\text { Growth } \\
\text { parameters }\end{array}$ & $\begin{array}{l}\text { short } \\
\text { stature }\end{array}$ & $\begin{array}{l}\text { Ht: }-2.2 \text { SD } \\
\text { Wt: }-3.0 \mathrm{SD} \\
\text { OFC: }-3.6 \mathrm{SD}\end{array}$ & $\begin{array}{l}\text { Ht: }-1 \text { SD } \\
\text { Wt }<<5 \text { th \%ile } \\
\text { OFC }<5 \text { th \%ile }\end{array}$ & $\begin{array}{l}\mathrm{Ht}:-1.5 \mathrm{SD} \\
\mathrm{Wt}:-2.4 \mathrm{SD} \\
\text { OFC: }-4.1 \mathrm{SD}\end{array}$ & $\begin{array}{l}\text { Ht: }-1.6 \mathrm{SD} \\
\mathrm{Wt}:-1.4 \mathrm{SD} \\
\text { OFC: }-2.6 \mathrm{SD}\end{array}$ & $\begin{array}{l}\text { Ht: }-1.45 \text { SD } \\
\text { Wt: }-1.0 \mathrm{SD} \\
\text { OFC: }-2.0 \mathrm{SD}\end{array}$ & $\begin{array}{l}\text { Ht: }-3.5 \mathrm{SD} \\
\mathrm{Wt}:-3.5 \mathrm{SD} \\
\text { OFC: }-3.8 \mathrm{SD}\end{array}$ & $\begin{array}{l}\text { Ht: }-4.1 \text { SD } \\
\text { Wt: }-3.5 \mathrm{SD} \\
\text { OFC: }-4.4 \mathrm{SD}\end{array}$ & $\begin{array}{l}\text { Ht: }+0.7 \text { SD } \\
\text { Wt: }+0.2 \text { SD } \\
\text { OFC: }-3.9 \text { SD }\end{array}$ \\
\hline $\begin{array}{l}\text { Dysmorphic } \\
\text { features }\end{array}$ & NS & NS & $\begin{array}{l}\text { hypertelorism, } \\
\text { large PF, pectus } \\
\text { excavatum }\end{array}$ & $\begin{array}{l}\text { epicanthal folds, } \\
\text { hypotelorism, } \\
\text { long philtrum, } \\
\text { upturned nose, } \\
\text { full lips, } \\
\text { micrognathia }\end{array}$ & $\begin{array}{l}\text { upslanting PF, } \\
\text { bilateral epi- } \\
\text { canthal folds, } \\
\text { thin upper lip, } \\
\text { mild bitemporal } \\
\text { narrowing, } \\
\text { upturned nose }\end{array}$ & $\begin{array}{l}\text { right class II } \\
\text { microtia }\end{array}$ & $\begin{array}{l}\text { epicanthal } \\
\text { folds }\end{array}$ & - & $\begin{array}{l}\text { hypertelorism } \\
\text { with telecan- } \\
\text { thus, narrow PF, } \\
\text { hypoplastic alae } \\
\text { nasi, microgna- } \\
\text { thia }\end{array}$ \\
\hline $\begin{array}{l}\text { Skeletal } \\
\text { and digital } \\
\text { anomalies }\end{array}$ & NS & NS & - & $\begin{array}{l}\text { 5th finger } \\
\text { clinodactyly }\end{array}$ & $\begin{array}{l}\text { mild 5th } \\
\text { finger } \\
\text { clinodactyly }\end{array}$ & $\begin{array}{l}\text { right thumb } \\
\text { duplication }\end{array}$ & $\begin{array}{l}\text { prominent } \\
\text { finger fat pads }\end{array}$ & $\begin{array}{l}\text { short 5th fingers, } \\
\text { possibly short } \\
\text { ulna }\end{array}$ & $\begin{array}{l}\text { metopic } \\
\text { synostosis, } \\
\text { left clubfoot }\end{array}$ \\
\hline $\begin{array}{l}\text { Family } \\
\text { history }\end{array}$ & NS & NS & $\begin{array}{l}\text { maternal aunt } \\
\text { with cerebral } \\
\text { palsy }\end{array}$ & $\begin{array}{l}\text { mother's Ht: } \\
-0.8 \mathrm{SD}, \mathrm{OFC} \text { : } \\
-3.8 \mathrm{SD}, \\
\text { overweight, LD, } \\
\text { depression; } \\
\text { father's Ht: } \\
-2.6 \mathrm{SD}, \mathrm{ADHD}\end{array}$ & \multicolumn{2}{|c|}{$\begin{array}{l}\text { mother's Ht: }-1.7 \text { SD, } \\
\text { microcephalic, IQ 50-60, } \\
\text { does not have custody of } \\
\text { children }\end{array}$} & $\begin{array}{l}\text { mother's Ht: } \\
+0.3 \mathrm{SD} ; \\
\text { father's Ht: } \\
-0.7 \mathrm{SD} ; \\
\text { brother's Ht: } \\
\text { (at } 6 \text { y) + } 2 \mathrm{SD}\end{array}$ & $\begin{array}{l}\text { mother's Ht: } \\
-1.7 \text { SD, possible } \\
\text { LD; brother } \\
\text { (not tested) has } \\
\text { LD, behavior } \\
\text { problems, nl } \\
\text { stature }\end{array}$ & NS \\
\hline
\end{tabular}

$\mathrm{y}=$ Years; $\mathrm{m}=$ months; $\mathrm{Ht}=$ height; $\mathrm{SD}=$ standard deviation; $\mathrm{Wt}=$ weight $\mathrm{OFC}=$ occipitofrontal circumference; $\mathrm{NA}=$ not available; $\mathrm{DD}=$ developmental delay; $\mathrm{ADHD}=$ attention deficit hyperactivity disorder; $\mathrm{NS}=$ not specified; $\mathrm{nl}=$ normal; $\mathrm{PF}=$ palpebral fissures; $\mathrm{EEG}=$ electroencephalogram; $\mathrm{DTR}$ = deep tendon reflexes; $\mathrm{LD}=$ learning disability; IQ = intelligence quotient; - = feature absent.

\section{Results}

Out of 53,059 probands' samples tested at Signature Genomics, $9(0.017 \%)$ had interstitial duplications involving NSD1: 6 were whole-gene duplications (3 reciprocal to the recurrent $\sim 2.0-\mathrm{Mb}$ Sotos syndrome deletion), and 3 only partially duplicated NSD1. Clinical information was available for 6 of these 9 probands and for 2 probands tested at other laboratories; duplications range in size from $370 \mathrm{~kb}-$ 3.7 $\mathrm{Mb}$ (table 1, fig. 1). None of these individuals (represented in table 1) carry any other clinically significant CNVs. Two of the $>1.5-\mathrm{Mb}$ duplications are apparently de 


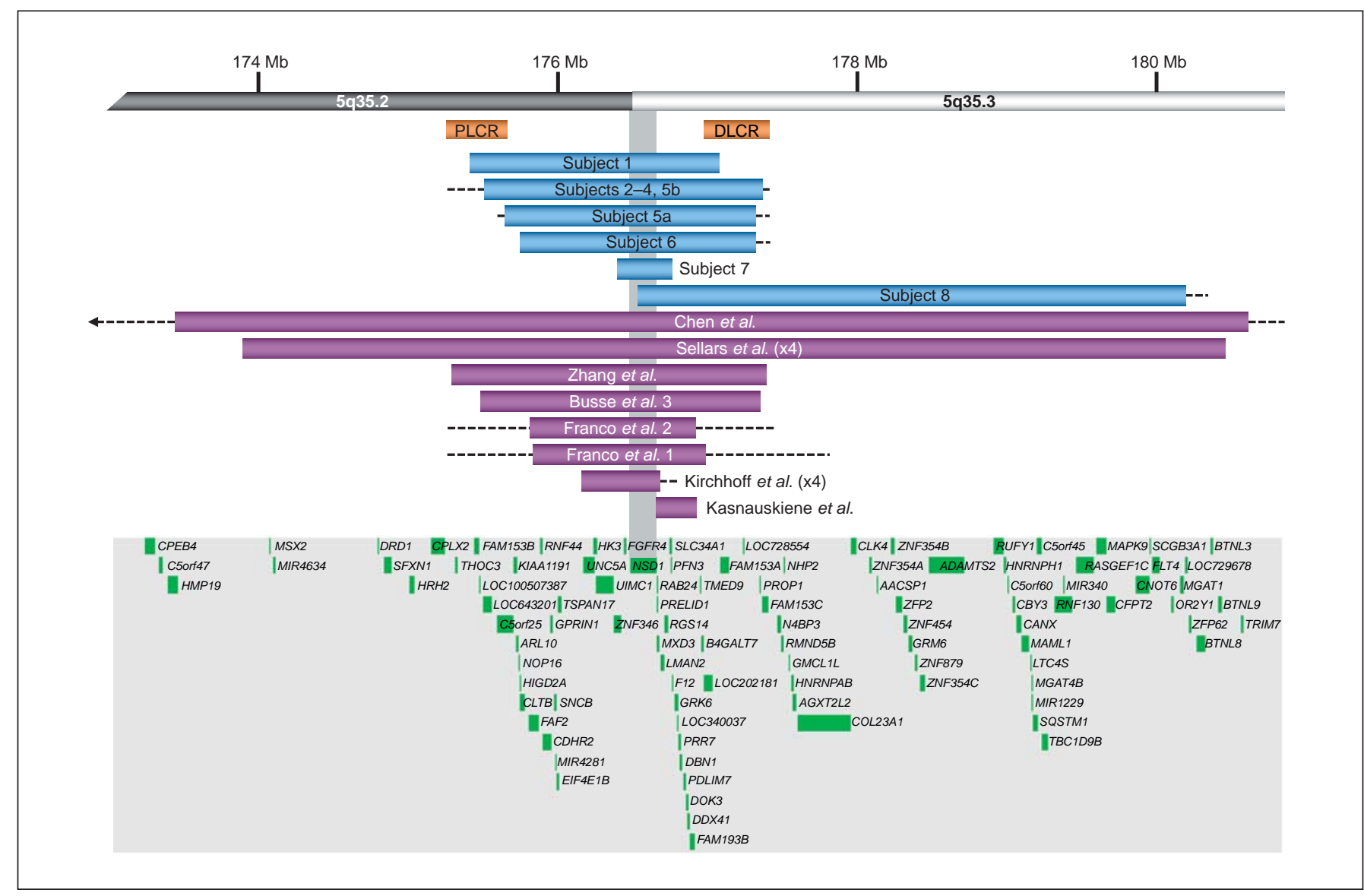

Fig. 1. Duplications in the $5 \mathrm{q} 35$ Sotos syndrome region in this cohort and the published literature. At the top of the figure is a partial idiogram showing chromosome bands 5q35.2qter with genomic coordinates corresponding to the hg18 build of the human genome. Orange bars represent the proximal and distal low-copy repeats (PLCR and DLCR) that mediate recurrent deletions and duplications [Mochizuki et al., 2008]. Blue and purple bars repre- sent the duplications in this cohort and those in the literature, respectively. Tetrasomic individuals are indicated by the text ' $\mathrm{x} 4$ '. Horizontal dashed lines extend through gaps in probe coverage to show the maximum possible size of duplications. Green bars represent the genes in this region, and the vertical, gray-shaded region marks the location of NSD1. novo, whereas one small duplication (in subject 7; $370 \mathrm{~kb}$ ) and one recurrent reciprocal duplication (in subject 4) were inherited from affected mothers, and another recurrent reciprocal duplication (in subjects $5 \mathrm{a}$ and $5 \mathrm{~b}$ ) is inferred to be carried by the half-siblings' affected mother. All individuals with whole-gene duplications of NSD1 have growth parameters that range from severely restricted to below average, with a mean height of -1.96 standard deviations (SD) and mean head size of $-3.5 \mathrm{SD}$. Children with NSD1 duplications have a mean weight of $-2.47 \mathrm{SD}$, whereas at least one carrier mother is overweight.

A comparison of the frequency of whole-gene NSD1 duplications in our clinical aCGH population to that among published controls [Shaikh et al., 2009; Cooper et al., 2011] showed no significant difference $(6 / 53,059$ cases vs. $0 / 10,355$ controls; one-tailed $p=0.34$, Fisher's exact test). Due to the rarity of the duplication, larger populations are required for a more meaningful comparison.

\section{Discussion}

We report 12 individuals from 8 families with interstitial 5q duplications involving NSD1; all but one (subject 8) have a whole-gene duplication. The majority of these duplications are reciprocal to the recurrent $\sim 2.0-\mathrm{Mb}$ deletion seen in some individuals with Sotos syndrome. Our cohort also includes a mother and son who carry one of the smallest whole-gene NSD1 duplications reported to date (subject 7, fig. 1). Similar to previous reports of inter- 
Table 2. Summary of phenotypes among individuals with wholegene NSD1 duplications

\begin{tabular}{lc}
\hline Feature & $\begin{array}{c}\text { Frequency } \\
(\text { mean } z \text {-score })^{\mathrm{a}}\end{array}$ \\
\hline Short stature & $9 / 18(-2.4)$ \\
Underweight & $9 / 13(-2.9)$ \\
Microcephaly & $16 / 16(-3.6)$ \\
Delayed bone age & $2 / 2$ \\
Developmental delay & $17 / 17$ \\
Hypotonia & $2 / 13$ \\
Behavioral abnormalities & $3 / 13$ \\
Hearing loss & $2 / 13$ \\
Seizures or abnormal EEG & $2 / 13$ \\
Brain abnormalities & $2 / 6$ \\
Strabismus & $2 / 13$ \\
Dysmorphism & $9 / 13$ \\
Digital anomalies & $7 / 13$ \\
Heart defects, structural and functional & $3 / 14$ \\
Hernias & $1 / 13$ \\
\hline
\end{tabular}

${ }^{a}$ Includes all 11 subjects (probands and family members) in this report with whole-gene duplications and probands previously reported with molecularly defined duplication [Chen et al., 2006; Franco et al., 2010; Busse et al., 2011; Zhang et al., 2011] or triplication [Kirchhoff et al., 2007; Sellars et al., 2011] of NSD1.

stitial 5q35 NSD1 duplications [Kirchhoff et al., 2007; Franco et al., 2010; Busse et al., 2011; Zhang et al., 2011] and larger, terminal $5 \mathrm{q} 35$ duplications in individuals with Hunter-McAlpine syndrome [Hunter et al., 2005; Chen et al., 2006; Sellars et al., 2011], growth retardation (especially microcephaly) and developmental delay (DD) or LD are prominent features in the majority of the individuals in our cohort (tables 1 and 2). While the prevalence of DD/ LD in our cohort could be influenced by an ascertainment bias, as these are common indications for referral for clinical microarray-based testing, 3 carrier mothers also have intellectual or learning disabilities, supporting a causative association between NSD1 duplications and DD/LD. Additional neurological features, including hypotonia, abnormal behaviors and seizures or EEG abnormalities, are reported in a minority of individuals with NSD1 duplications. Dysmorphic features, frequently mild, as well as digital anomalies, including clinodactyly (subjects 4 and 5a), brachydactyly [Chen et al., 2006; Zhang et al., 2011] (subject 7), syndactyly [Zhang et al., 2011], polydactyly (subject 5b), and absent thumbs [Sellars et al., 2011], are also present in a majority of individuals (table 2). Brachydactyly was also reported in the original family described with Hunter-McAlpine syndrome, though both balanced translocation carriers and individuals with $5 \mathrm{q}$ duplica- tions due to unbalanced translocations demonstrated this phenotype [Hunter et al., 2005]. Finally, subject 7 in our cohort has significantly delayed bone age, representing a second report of this feature with NSD1 duplication and another example of an opposite feature from Sotos syndrome [Franco et al., 2010].

Phenotypes of individuals with NSD1 duplications may be affected by the presence of additional genes within their duplications, similar to what is seen with deletions in the region. In general, individuals with Sotos syndrome carrying deletions that include genes other than NSD1 have increased severity of LD, less pronounced overgrowth and, more commonly, cardiac anomalies and seizures [Nagai et al., 2003; Tatton-Brown et al., 2005b; Saugier-Veber et al., 2007]. Specific additional phenotypes are attributable to genes in the region: deletion of SLC34A1 can lead to nephrocalcinosis and/or infantile hypercalcemia [Kenny et al., 2011], and factor XII deficiency may exist, depending on the genotype of the nondeleted F12 allele [Kurotaki et al., 2005].

A majority of individuals reported with NSD1 duplications have had digital anomalies (table 2). This phenotype may be attributable to, or influenced by, the duplication of PDLIM7, which encodes a PDZ-LIM scaffold protein that binds both actin and Tbx5, sequestering and repressing this transcription factor that has key roles in heart and limb development [Krause et al., 2004; Camarata et al., 2006]. It is known that haploinsufficiency for TBX5 causes Holt-Oram syndrome with characteristic thumb anomalies and heart defects [Basson et al., 1997; Li et al., 1997], and knockdown of Pdlim7 in zebrafish results in heart and pectoral fin (limb) defects [Camarata et al. 2010a, b]. Among individuals reported with $5 \mathrm{q} 35$ duplications, the more severe digital anomalies involve the thumbs, preaxial polydactyly in subject $5 \mathrm{~b}$ and absent thumbs in a previously reported case [Sellars et al., 2011], consistent with TBX5 defects. The patient with absent thumbs reported by Sellars et al. [2011] had tetrasomy of a 6.6-Mb interstitial 5q35 segment, possibly suggesting more severe effects with 2 extra copies of PDLIM7, although the large region of tetrasomy may contain additional genes contributing to the phenotype. Interestingly, subject 7, whose duplication does not involve PDLIM7, has short fifth fingers and possibly a short ulna, which may indicate that NSD1 (which helps regulate proper expression of bone morphogenic protein 4, BMP4 [Lucio-Eterovic et al., 2010]) or other genes in the duplicated region may also be altering skeletal development. Additionally, the interaction of Pdlim7 with Tbx 5 in animal models makes PDLIM7 a candidate for the heart defects. However, such malformations have 
been rarely reported; subject 2 in our cohort has hypoplastic left heart, and subject 8 has an atrial septal defect; the case with tetrasomy of this region reported by Sellars et al. [2011] showed ventricular noncompaction, and a previously reported individual with a recurrent duplication had a ventricular septal defect [Busse et al., 2011].

The small duplication in subject 7 and his mother helps to narrow the critical region for the microcephaly, short stature and LD/DD phenotype associated with these duplications. This duplication includes, at most, 12 genes, including NSD1 (fig. 1). Subject 8, whose shared duplication region with subject 7 includes 9 whole genes, does not show the below average stature that all other subjects in this cohort display. Also unlike the other subjects in our cohort, subject 8 cannot have a third, intact, functional copy of NSD1. Subject 8 does have significant microcephaly, and while this may indicate that microcephaly can be caused by duplication of a gene distal to NSD1, this could also be attributable to her craniosynostosis. Furthermore, Kasnauskiene et al. [2011] reported an individual presenting with a Sotos syndrome phenotype with a duplication overlapping the distal end of subject 7's duplication region (fig. 1). The mechanism through which this duplication may be interfering with NSD1 expression remains to be determined, but combining this report with subject 8's phenotype makes it less likely that duplication of the genes distal to NSD1 are responsible for growth retardation. This leaves 3 genes uniquely duplicated in our subjects with growth retardation: ZNF346, FGFR4 and NSD1. Fibroblast growth factor receptor 4 (FGFR4) is a positive regulator of growth [Lazarus et al., 2007], so it is an unlikely candidate for causing growth retardation. ZNF346 encodes a zinc finger protein that binds double-stranded RNA, and its overexpression in vitro induces apoptosis [Yang et al., 1999], so this gene could feasibly contribute to growth retardation. However, duplication of the entire $N S D 1$ gene remains a strong candidate for causing growth restriction. It encodes the nuclear receptor-binding SET domain-containing protein 1 , a methyltransferase that works on histones to help regulate proper gene expression [Lucio-Eterovic et al., 2010; Wagner and Carpenter, 2012]. It is feasible that overexpression of NSD1 could drive expression of its target genes in an opposite pattern from what occurs with NSD1 haploinsufficiency, resulting in an opposite phenotype. Similar examples are in the literature of genes having opposite effects on growth with gain or loss of function, such as KCTD13 within 16p11.2 [Golzio et al., 2012], the $A K T$ genes [Hussain et al., 2011; Lindhurst et al., 2011; Poduri et al., 2012; Riviere et al., 2012] and FGFR3 [Foldynova-Trantirkova et al., 2012].
Subject 8 (with a 3.7-Mb duplication) has craniosynostosis, a feature occasionally seen with terminal $5 \mathrm{q}$ duplications that has been previously attributed to MSX2 [Kariminejad et al., 2009]. Our subject represents the first description of a molecularly characterized $5 \mathrm{q} 35$ duplication sparing MSX2 in an individual with craniosynostosis. It is still likely that MSX2 duplication contributes to craniosynostosis in the previously reported individuals, given that mutations in MSX2 cause craniosynostosis [Jabs et al., 1993], as does overexpression in mice [Liu et al., 1995]. We cannot rule out that subject 8's duplication interferes with proper MSX2 expression, particularly as the gene is hypothesized to be regulated by noncoding elements distant from the gene [Ott et al., 2012] and, therefore, may be more sensitive to changes in chromatin conformation. Alternatively, other genes in distal $5 \mathrm{q} 35$ have roles in bone development, and overexpression of these may also cause or contribute to the craniosynostosis in subject 8 . There are several candidates in the region. PDLIM7 expression induces bone formation [Boden et al., 1998; Liu et al., 2002]. ZNF354C encodes a transcription repressor involved in osteoblastic differentiation and overexpression of which can induce bone formation [Jheon et al., 2009]. MAPK9 encodes a kinase involved in signal transduction pathways that is required for late-stage differentiation of osteoblasts and overexpression of which causes increased mineral deposition in bone [Matsuguchi et al., 2009]. Additional genes in the region may also play roles in bone formation, including HNRNPAB [Fomenkov et al., 2003], ADAMTS2 [Bar-Yosef et al., 2008] and SQSTM1 [Chamoux et al., 2009; McManus and Roux, 2012], although there is insufficient literature to support a direct mechanism of a copy gain of these genes. Finally, it is possible that subject 8's craniosynostosis is secondary to her microcephaly, and duplication of one or more genes distal to NSD1 causes microcephaly, as opposed to causing craniosynostosis.

Molecular cytogenetic testing in individuals with neurodevelopmental disease and congenital anomalies has led to the discovery of many recurrent microdeletion and microduplication syndromes. The microdeletion syndromes are frequently the first to be characterized, often because the phenotypes are more severe, and more variability is seen with reciprocal microduplications. For some of these characterized reciprocal duplications, like those of distal 1q21.1 and proximal 16p11.2, an apparent opposite effect on growth emerges [Brunetti-Pierri et al., 2008; Shinawi et al., 2010]. We report a cohort of individuals with microduplications reciprocal to the $\sim 2.0$ $\mathrm{Mb} 5 \mathrm{q} 35.2 \mathrm{q} 35.3$ deletions that cause the Sotos overgrowth syndrome. The duplications cause growth retar- 
dation; the most notable is microcephaly, but height and childhood weight also range from below average to severely restricted. Therefore, duplications of the Sotos syndrome region are another example of a reciprocal duplication demonstrating an opposite effect on growth as compared to the deletion phenotype. With some deletions/duplications, single genes have been implicated in these effects on growth [Golzio et al., 2012], whereas with others the effects may rely on the involvement of a larger region and perhaps inclusion of multiple genes [Lacaria et al., 2012]. Given the growth retardation and small duplication in subject 7 and subject 8 's above average stature and only partial duplication of NSD1, it is likely that whole-gene duplication of NSD1 alone is sufficient to cause the growth phenotype, though this remains to be definitively proven. We also show that duplication carriers frequently have DD/LD and occasionally other congenital anomalies, providing a more complete phenotypic picture for these reciprocal Sotos-region duplications.

\section{Acknowledgements}

The authors thank the subjects' families for their participation in this study. We also thank Erin Dodge and A. Michelle Caldwell (Signature Genomic Laboratories) for editorial assistance and figure creation.

\section{References}

Ballif BC, Theisen A, Coppinger J, Gowans GC, Busse T, Graham JM Jr, Feldman G, Perin J, Hersh JH, et al: Expanding the clinical phenotype of the $3 \mathrm{q} 29$ microdeletion syndrome and characterization of the reciprocal microduplication. Mol Cytogenet 1:8 (2008a).

Ballif BC, Theisen A, McDonald-McGinn DM, Zackai EH, Hersh JH, et al: Identification of a previously unrecognized microdeletion syndrome of 16q11.2q12.2. Clin Genet 74: 469-475 (2008b).

Ballif BC, Rosenfeld JA, Traylor R, Theisen A, Bader PI, et al: High-resolution array CGH defines critical regions and candidate genes for microcephaly, abnormalities of the corpus callosum, and seizure phenotypes in patients with microdeletions of 1q43q44. Hum Genet 131:145-156 (2012).

Bar-Yosef O, Polak-Charcon S, Hoffman C, Feldman ZP, Frydman M, Kuint J: Multiple congenital skull fractures as a presentation of Ehlers-Danlos syndrome type VIIC. Am J Med Genet A 146A:3054-3057 (2008).

-Basson CT, Bachinsky DR, Lin RC, Levi T, Elkins JA, et al: Mutations in human TBX5 [corrected] cause limb and cardiac malformation in Holt-Oram syndrome. Nat Genet 15:30-35 (1997).

-Bejjani BA, Saleki R, Ballif BC, Rorem EA, Sundin K, et al: Use of targeted array-based CGH for the clinical diagnosis of chromosomal imbalance: is less more? Am J Med Genet A 134:259-267 (2005).

-Boden SD, Liu Y, Hair GA, Helms JA, Hu D, et al: LMP-1, a LIM-domain protein, mediates BMP-6 effects on bone formation. Endocrinology 139:5125-5134 (1998).

-Brunetti-Pierri N, Berg JS, Scaglia F, Belmont J, Bacino CA, et al: Recurrent reciprocal 1q21.1 deletions and duplications associated with microcephaly or macrocephaly and developmental and behavioral abnormalities. Nat Genet 40:1466-1471 (2008). Catherwood A, et al: High-Resolution genomic arrays identify CNVs that phenocopy the chromosome 22q11.2 deletion syndrome. Hum Mutat 32:91-97 (2011).

- Camarata T, Bimber B, Kulisz A, Chew TL, Yeung J, Simon HG: LMP4 regulates Tbx5 protein subcellular localization and activity. J Cell Biol 174:339-348 (2006).

Camarata T, Krcmery J, Snyder D, Park S, Topczewski J, Simon HG: Pdlim7 (LMP4) regulation of Tbx 5 specifies zebrafish heart atrioventricular boundary and valve formation. Dev Biol 337:233-245 (2010a).

Camarata T, Snyder D, Schwend T, Klosowiak J, Holtrup B, Simon HG: Pdlim7 is required for maintenance of the mesenchymal/epidermal Fgf signaling feedback loop during zebrafish pectoral fin development. BMC Dev Biol 10: 104 (2010b).

Chamoux E, Couture J, Bisson M, Morissette J, Brown JP, Roux S: The p62 P392L mutation linked to Paget's disease induces activation of human osteoclasts. Mol Endocrinol 23: 1668-1680 (2009).

Chen CP, Lin SP, Lin CC, Chen YJ, Chern SR, et al: Molecular cytogenetic analysis of de novo $\operatorname{dup}(5)(q 35.2 q 35.3)$ and review of the literature of pure partial trisomy 5q. Am J Med Genet A 140:1594-1600 (2006).

Chen WS, Xu PZ, Gottlob K, Chen ML, Sokol K, et al: Growth retardation and increased apoptosis in mice with homozygous disruption of the Akt1 gene. Genes Dev 15:22032208 (2001).

Cooper GM, Coe BP, Girirajan S, Rosenfeld JA, $\mathrm{Vu} \mathrm{TH}$, et al: A copy number variation morbidity map of developmental delay. Nat Genet 43:838-846 (2011).

Crespi B, Summers K, Dorus S: Genomic sisterdisorders of neurodevelopment: an evolutionary approach. Evolutionary Applications 2:81-100 (2009).
Crespi B, Stead P, Elliot M: Evolution in health and medicine Sackler colloquium: comparative genomics of autism and schizophrenia. Proc Natl Acad Sci USA 107 Suppl 1:17361741 (2010).

Douglas J, Tatton-Brown K, Coleman K, Guerrero S, Berg J, et al: Partial NSD1 deletions cause $5 \%$ of Sotos syndrome and are readily identifiable by multiplex ligation dependent probe amplification. J Med Genet 42:e56 (2005).

Duker AL, Ballif BC, Bawle EV, Person RE, Mahadevan S, et al: Paternally inherited microdeletion at $15 \mathrm{q} 11.2$ confirms a significant role for the SNORD116 C/D box snoRNA cluster in Prader-Willi syndrome. Eur J Hum Genet 18:1196-1201 (2010).

Foldynova-Trantirkova S, Wilcox WR, Krejci P. Sixteen years and counting: the current understanding of fibroblast growth factor receptor 3 (FGFR3) signaling in skeletal dysplasias. Hum Mutat 33:29-41 (2012).

Fomenkov A, Huang YP, Topaloglu O, Brechman A, Osada M, et al: P63 alpha mutations lead to aberrant splicing of keratinocyte growth factor receptor in the Hay-Wells syndrome. J Biol Chem 278:23906-23914 (2003).

Franco LM, de Ravel T, Graham BH, Frenkel SM, Van Driessche J, et al: A syndrome of short stature, microcephaly and speech delay is associated with duplications reciprocal to the common Sotos syndrome deletion. Eur J Hum Genet 18:258-261 (2010).

Gajecka M, Yu W, Ballif BC, Glotzbach CD, Bailey KA, et al: Delineation of mechanisms and regions of dosage imbalance in complex rearrangements of 1 p36 leads to a putative gene for regulation of cranial suture closure. Eur J Hum Genet 13:139-149 (2005).

-George S, Rochford JJ, Wolfrum C, Gray SL, Schinner S, et al: A family with severe insulin resistance and diabetes due to a mutation in AKT2. Science 304:1325-1328 (2004). 
Golzio C, Willer J, Talkowski ME, Oh EC, Taniguchi Y, et al: KCTD13 is a major driver of mirrored neuroanatomical phenotypes of the $16 \mathrm{p} 11.2$ copy number variant. Nature 485:363-367 (2012).

-Hunter AG, Dupont B, McLaughlin M, Hinton L, Baker E, et al: The Hunter-McAlpine syndrome results from duplication 5q35-qter. Clin Genet 67:53-60 (2005).

-Hussain K, Challis B, Rocha N, Payne F, Minic $\mathrm{M}$, et al: An activating mutation of $A K T 2$ and human hypoglycemia. Science 334:474 (2011).

-Jabs EW, Muller U, Li X, Ma L, Luo W, et al: A mutation in the homeodomain of the human MSX2 gene in a family affected with autosomal dominant craniosynostosis. Cell 75 : 443-450 (1993).

-Jacquemont S, Reymond A, Zufferey F, Harewood L, Walters RG, et al: Mirror extreme BMI phenotypes associated with gene dosage at the chromosome 16p11.2 locus. Nature 478:97-102 (2011).

-Jheon A, Bansal AK, Zhu B, Ganss B, Cheifetz S, Sodek J: Characterisation of the constitutive over-expression of AJ18 in a novel rat stromal bone marrow cell line (D8-SBMC). Arch Oral Biol 54:705-716 (2009).

-Kariminejad A, Kariminejad R, Tzschach A, Ullmann R, Ahmed A, et al: Craniosynostosis in a patient with 2 q37.3 deletion $5 q 34$ duplication: association of extra copy of MSX2 with craniosynostosis. Am J Med Genet A 149A:1544-1549 (2009).

- Kasnauskiene J, Cimbalistiene L, Ciuladaite Z, Preiksaitiene E, Kucinskiene ZA, et al: De novo $5 \mathrm{q} 35.5$ duplication with clinical presentation of Sotos syndrome. Am J Med Genet A 155A:2501-2507 (2011).

Kenny J, Lees MM, Drury S, Barnicoat A, Van't Hoff W, et al: Sotos syndrome, infantile hypercalcemia, and nephrocalcinosis: a contiguous gene syndrome. Pediatr Nephrol 26 : 1331-1334 (2011).

Kirchhoff M, Bisgaard AM, Bryndorf T, Gerdes T: MLPA analysis for a panel of syndromes with mental retardation reveals imbalances in $5.8 \%$ of patients with mental retardation and dysmorphic features, including duplications of the Sotos syndrome and WilliamsBeuren syndrome regions. Eur J Med Genet 50:33-42 (2007).

Krause A, Zacharias W, Camarata T, Linkhart B, Law E, et al: Tbx 5 and Tbx4 transcription factors interact with a new chicken PDZLIM protein in limb and heart development. Dev Biol 273:106-120 (2004).

Kurotaki N, Harada N, Shimokawa O, Miyake N, Kawame H, et al: Fifty microdeletions among 112 cases of Sotos syndrome: low copy repeats possibly mediate the common deletion. Hum Mutat 22:378-387 (2003).

-Kurotaki N, Shen JJ, Touyama M, Kondoh T, Visser R, et al: Phenotypic consequences of genetic variation at hemizygous alleles: Sotos syndrome is a contiguous gene syndrome in- corporating coagulation factor twelve (FXII) deficiency. Genet Med 7:479-483 (2005).

Lacaria M, Saha P, Potocki L, Bi W, Yan J, et al: A duplication $\mathrm{CNV}$ that conveys traits reciprocal to metabolic syndrome and protects against diet-induced obesity in mice and men. PLoS Genet 8:e1002713 (2012).

- Lazarus JE, Hegde A, Andrade AC, Nilsson O, Baron J: Fibroblast growth factor expression in the postnatal growth plate. Bone 40:577586 (2007).

Li QY, Newbury-Ecob RA, Terrett JA, Wilson DI, Curtis AR, et al: Holt-Oram syndrome is caused by mutations in TBX5, a member of the Brachyury (T) gene family. Nat Genet 15: 21-29 (1997).

- Lindhurst MJ, Sapp JC, Teer JK, Johnston JJ, Finn EM, et al: A mosaic activating mutation in AKT1 associated with the Proteus syndrome. N Engl J Med 365:611-619 (2011).

- Liu Y, Hair GA, Boden SD, Viggeswarapu M, Titus L: Overexpressed LIM mineralization proteins do not require LIM domains to induce bone. J Bone Miner Res 17:406-414 (2002).

Liu YH, Kundu R, Wu L, Luo W, Ignelzi MA Jr, et al: Premature suture closure and ectopic cranial bone in mice expressing $M s \times 2$ transgenes in the developing skull. Proc Natl Acad Sci USA 92:6137-6141 (1995).

Lucio-Eterovic AK, Singh MM, Gardner JE, Veerappan CS, Rice JC, Carpenter PB: Role for the nuclear receptor-binding SET domain protein 1 (NSD1) methyltransferase in coordinating lysine 36 methylation at histone 3 with RNA polymerase II function. Proc Natl Acad Sci USA 107:16952-16957 (2010).

Matsuguchi T, Chiba N, Bandow K, Kakimoto K, Masuda A, Ohnishi T: JNK activity is essential for Atf4 expression and late-stage osteoblast differentiation. J Bone Miner Res 24: 398-410 (2009).

-McManus S, Roux S: The adaptor protein p62/ SQSTM1 in osteoclast signaling pathways. J Mol Signal 7:1 (2012).

Mochizuki J, Saitsu H, Mizuguchi T, Nishimura A, Visser R, et al: Alu-related 5q35 microdeletions in Sotos syndrome. Clin Genet 74: 384-391 (2008).

- Nagai T, Matsumoto N, Kurotaki N, Harada N, Niikawa N, et al: Sotos syndrome and haploinsufficiency of NSD1: clinical features of in tragenic mutations and submicroscopic deletions. J Med Genet 40:285-289 (2003).

-Ott CE, Hein H, Lohan S, Hoogeboom J, Foulds $\mathrm{N}$, et al: Microduplications upstream of MSX2 are associated with a phenocopy of cleidocranial dysplasia. J Med Genet 49:437441 (2012).

Poduri A, Evrony GD, Cai X, Elhosary PC, Beroukhim R, et al: Somatic activation of AKT3 causes hemispheric developmental brain malformations. Neuron 74:41-48 (2012).

Riviere JB, Mirzaa GM, O’Roak BJ, Beddaoui M, Alcantara D, et al: De novo germline and postzygotic mutations in $A K T 3, P I K 3 R 2$ and PIK3CA cause a spectrum of related megalencephaly syndromes. Nat Genet 44:934940 (2012).

-Saugier-Veber P, Bonnet C, Afenjar A, DrouinGarraud V, Coubes C, et al: Heterogeneity of NSD1 alterations in 116 patients with Sotos syndrome. Hum Mutat 28:1098-1107 (2007).

Sellars EA, Zimmerman SL, Smolarek T, Hopkin RJ: Ventricular noncompaction and absent thumbs in a newborn with tetrasomy $5 \mathrm{q} 35.2$ 5q35.3: an association with Hunter-McAlpine syndrome? Am JMed Genet A 155A:14091413 (2011).

- Shaikh TH, Gai X, Perin JC, Glessner JT, Xie H, et al: High-resolution mapping and analysis of copy number variations in the human genome: a data resource for clinical and research applications. Genome Res 19:16821690 (2009).

-Shinawi M, Liu P, Kang SH, Shen J, Belmont JW, et al: Recurrent reciprocal $16 \mathrm{p} 11.2$ rearrangements associated with global developmental delay, behavioural problems, dysmorphism, epilepsy, and abnormal head size. J Med Genet 47:332-341 (2010).

Tatton-Brown K, Douglas J, Coleman K, Baujat G, Chandler K, et al: Multiple mechanisms are implicated in the generation of $5 \mathrm{q} 35 \mathrm{mi}$ crodeletions in Sotos syndrome. J Med Genet 42:307-313 (2005a)

Tatton-Brown K, Douglas J, Coleman K, Baujat G, Cole TR, et al: Genotype-phenotype associations in Sotos syndrome: an analysis of 266 individuals with NSD1 aberrations. Am J Hum Genet 77:193-204 (2005b).

- Traylor RN, Fan Z, Hudson B, Rosenfeld JA, Shaffer LG, et al: Microdeletion of 6q16.1 encompassing EPHA7 in a child with mild neurological abnormalities and dysmorphic features: case report. Mol Cytogenet 2:17 (2009).

-Visser R, Shimokawa O, Harada N, Kinoshita A, Ohta T, et al: Identification of a 3.0-kb major recombination hotspot in patients with Sotos syndrome who carry a common $1.9-\mathrm{Mb} \mathrm{mi}-$ crodeletion. Am J Hum Genet 76:52-67 (2005).

-Wagner EJ, Carpenter PB: Understanding the language of Lys 36 methylation at histone $\mathrm{H} 3$. Nat Rev Mol Cell Biol 13:115-126 (2012).

Wilkie AO, Tang Z, Elanko N, Walsh S, Twigg SR, et al: Functional haploinsufficiency of the human homeobox gene MSX2 causes defects in skull ossification. Nat Genet 24:387390 (2000).

Yang M, May WS, Ito T: JAZ requires the doublestranded RNA-binding zinc finger motifs for nuclear localization. J Biol Chem 274:27399_ 27406 (1999).

Zhang H, Lu X, Beasley J, Mulvihill JJ, Liu R, et al: Reversed clinical phenotype due to a microduplication of Sotos syndrome region detected by array CGH: microcephaly, developmental delay and delayed bone age. Am J Med Genet A 155A:1374-1378 (2011) 